\title{
Vrijheid in het vermogensrecht
}

\author{
Redactioneel \\ Mr.drs. P.A. Fruytier, mr. B. M. Paijmans, \\ mr. J.A. van der Weide en mr. R.M. de Winter*
}

\begin{abstract}
Het kalenderjaar 2020 zou voor Nederland in het teken staan van 75 jaar vrijheid. 'Zou', want dit jaar werd Nederland getroffen door de ergste crisis sinds de Tweede Wereldoorlog, in de vorm van een wereldwijde pandemie, veroorzaakt door het coronavirus (COVID-19). De voorbereidingen voor dit themanummer waren echter reeds in volle gang toen de coronacrisis zich aandiende, en aangezien de viering van 75 jaar vrijheid een feit van grote historische betekenis is, heeft de redactie van Maandblad voor Vermogensrecht besloten vast te houden aan het eerder gekozen thema 'Vrijheid in het vermogensrecht', in aansluiting bij dit bijzondere herdenkingsjaar.
\end{abstract}

Op 29 oktober 1941 hield de toenmalige Britse premier Sir Winston Churchill (1874-1965) op Harrow School te Londen, een elitaire kostschool voor jongens die hij zelf als leerling had bezocht, zijn vermaard geworden 'Never Give In'-speech. De toespraak was bestemd om het Britse oorlogsmoreel op te vijzelen in een tijd dat het Verenigd Koninkrijk betrekkelijk zwak en geïsoleerd stond in zijn strijd tegen nazi-Duitsland. De woorden die hij sprak, zijn onvergankelijk en strekken ter bemoediging in tijden van tegenspoed:

'But for everyone, surely, what we have gone through in this period - I am addressing myself to the School - surely from this period of ten months this is the lesson: never give in, never give in, never, never, never-in nothing, great or small, large or petty - never give in except to convictions of honour and good sense. Never yield to force; never yield to the apparently overwhelming might of the enemy.'

In dit themanummer treft u een tiental bijdragen aan rondom het thema 'Vrijheid in het vermogensrecht'. Het spectrum strekt zich daarbij uit van de (te) losse teugels in het nadeel-

Mr. drs. P.A. Fruytier is advocaat bij Houthoff te Amsterdam en redacteur van dit tijdschrift. Mr. B.M. Paijmans is advocaat bij Doelen Advocatuur te Utrecht, universitair docent bij het Molengraaff Instituut voor Privaatrecht van de Universiteit Utrecht en redacteur van dit tijdschrift. Mr. J.A. van der Weide is universitair hoofddocent aan de Universiteit Leiden, (onafhankelijk) legal counsellor en hoofdredacteur van dit tijdschrift. Mr. R.M. de Winter is raadsheer-plaatsvervanger bij gerechtshof Amsterdam en redacteur van dit tijdschrift. compensatierecht bij rechtmatig overheidshandelen tot aan de vrijheid om over data en informatie te beschikken.

Geheel in lijn met de viering van 75 jaar vrijheid analyseert Jansen in zijn rechtshistorisch getinte bijdrage de beknotting van privaatrechtelijke vrijheden tijdens de bezetting, zoals de contractsvrijheid en de vrijheid van eigendom. Hij laat zien dat de beperking van vrijheden in de private sector, die reeds in gang was gezet vóór de Tweede Wereldoorlog, werd gecontinueerd zowel tijdens als na de bezetting.

Ook in de bijdrage van Milo is eigendom - de vrijheid en beperking daarvan - een centraal thema, waarbij hij op de voet van art. 5:1 BW het eigendomsbegrip bespreekt vanuit het perspectief van de trias eigendom, persoon en zaak. De begrippen 'persoon' en 'zaak' gebruikt de auteur daarbij als eigenstandig bepalende factoren ter nadere invulling van het eigendomsconcept.

Zoals Van Hees ons in zijn artikel leert, stuit de vrijheid van pand- en hypotheekhouders om 'eigenstandig' tot uitwinning over te gaan van het met pand- of hypotheekrecht bezwaarde goed in de praktijk af op een aantal belemmeringen. Van Hees bespreekt er twee: (a) de beperkte mogelijkheden om bij faillissement van de schuldenaar tot verkoop van diens onderneming over te gaan teneinde een maximale opbrengst voor het onderpand te kunnen realiseren, en (b) de bevoegdheid die art. 58 lid $1 \mathrm{Fw}$ aan de curator geeft om de pand- of hypotheekhouder te dwingen binnen een redelijke termijn te executeren. Wettelijk ingrijpen lijkt in dit verband geboden.

Dat de faillissementscurator op zijn beurt weer aan grenzen is gebonden, wordt ons voorgehouden door Bentfort van Valkenburg en Van de Wiel. In hun bijdrage verkennen zij de grenzen van de beleidsvrijheid van de faillissementscurator aan de hand van een viertal ontwikkelingen die bij overtreding kunnen leiden tot persoonlijke aansprakelijkheid van de curator. Zo besteden zij onder meer aandacht aan de 'actieve' schending door de curator van een verplichting tot nalaten en de gehoudenheid van de curator tot fraudesignalering. Een van de remedies die door de auteurs wordt voorgesteld, is dat duidelijker wordt in welke gevallen de curator beleidsvrijheid 
heeft, want bij 'terughoudende en bange curatoren is geen enkele boedel gebaat'.

Faillissementscuratoren worden krachtens de wet (art. $14 \mathrm{Fw}$ ) door de rechtbank benoemd, maar de advocaat wordt 'vrij' door de justitiabele gekozen. Of de voor rechtsbijstand verzekerde justitiabele dezelfde vrijheid heeft, is echter de vraag. Holthinrichs gaat in zijn bijdrage in op de grote invloed die de jurisprudentie van het Europese Hof van Justitie heeft op de vrije advocaatkeuze voor rechtsbijstandverzekerden. Aandacht is er voor het recente arrest van 14 mei 2020, zaak C-667/18 (Orde van Vlaamse Balies/Ministerraad), waarin het Hof de vrije advocaatkeuze voor rechtsbijstandverzekerden verder heeft verruimd. Is het Hof bezig met de creatie van een Europees grondrecht voor rechtsbijstandverzekerden?

Ook Van Den Eeckhout laat in haar bijdrage zien dat het Europese recht en de rechtspraak van het Europese Hof van Justitie diep ingrijpen in de nationale rechtsordes van de lidstaten, in het bijzonder op het terrein van het internationaal privaatrecht. Het conflictenrechtelijke beginsel van de partijautonomie - de vrijheid van rechtskeuze - wordt 'beteugeld' zodra er bescherming dient plaats te vinden van zwakke partijen, zoals consumenten en werknemers (vgl. art. 6 en 8 Rome I). In haar bijdrage maant Van Den Eeckhout tot aandacht en waakzaamheid ten aanzien van de verhouding tussen 'vrijheid' enerzijds en 'bescherming van kwetsbare partijen' anderzijds.

Het Europese recht speelt ook een belangrijke rol in de bijdrage van Houben, die de vrijheid van banken bespreekt om de opening van een bankrekening te weigeren of een reeds geopende bankrekening op te zeggen. Het wettelijk recht op een basisbetaalrekening vindt zijn grondslag in de Europese betaalrekeningrichtlijn. ${ }^{1}$ De ratio achter de verplichting van banken om een betaalrekening te openen - een vorm van contractdwang - is volgens de auteur gelegen in het grote belang van de burger of een bedrijf om een betaalrekening te hebben. Tegelijkertijd verklaart dit ook de beperkte mogelijkheden tot opzegging van diezelfde betaalrekening door de bank, aldus Houben.

Een andere - ook in het Europese recht gegrondveste - dynamiek ontrolt zich in de bijdrage van Trojan en Kroeze. Zij richten zich in hun artikel op schadeclaims en de vrijheid van meningsuiting via de boeg van art. 8 en 10 EVRM en de rechtspraak van het Europees Hof voor de Rechten van de Mens over onrechtmatige perspublicaties. In hoeverre hebben eventuele juridische sancties, zoals schadevergoedingen, een ongewenst chilling effect op de persvrijheid? Van een dergelijk effect is sprake als het gebruik van een grondwettelijk recht, zoals de vrijheid van meningsuiting, door de mogelijkheid van of dreiging met sancties wordt ontmoedigd of verhinderd.
Compensatie van geleden schade komt ook aan bod in het artikel van Sluysmans en Van Triet, maar dan vanuit de invalshoek van het leerstuk van nadeelcompensatie bij rechtmatig overheidshandelen, zoals onteigening. Willekeurigheid lijkt hier troef. Aan de hand van een vijftal verschijningsvormen van de vrijheid van het bestuursorgaan bij de beoordeling van een verzoek tot nadeelcompensatie worden door de auteurs enkele harde noten gekraakt.

Information wants to be free. Van Engelen behandelt ten slotte het hoogstactuele thema van de vrijheid om over data en informatie te beschikken. In zijn bijdrage stelt hij vast dat het publiek belang bij en de grondrechtelijke aanspraak op publieke beschikbaarheid van data en informatie met zich brengen dat voor een inbreuk hierop tevens een duidelijke juridische grondslag is vereist. Die juridische grondslag wordt geboden door enerzijds het recht op eigendom en anderzijds het recht op privacy en de bescherming van persoonsgegevens.

Het motto van dit themanummer had ook kunnen zijn 'vrijheid in gebondenheid'. Op het eerste gezicht lijkt dit een innerlijke tegenstrijdigheid, maar schijn bedriegt. Vrijheid kan immers slechts tot volle wasdom komen, wanneer diezelfde vrijheid aan grenzen wordt gebonden. Dat is niet alleen in het belang van degene die zich op vrijheid beroept, maar juist ook in het belang van de ander wiens vrijheid daardoor wordt beperkt. Het is een belangrijk inzicht dat dit themanummer de lezer probeert mee te geven. Do ut des.

1. PbEU 2014, L 257/214. 